\title{
The Lioness Defending Her Clan in the North East: A Study of Ecospiritual Elements in Mamang Dai's Fiction
}

\author{
Meghamala Satapathy ${ }^{1} \&$ Ipsita Nayak $^{2}$ \\ ${ }^{1}$ PhD Research Scholar, KIIT Deemed to be University; Email: \\ satapathymeghamala@gmail.com; ORCID ID: https://orcid.org/oooo-ooo3-3519-766X \\ ${ }^{2}$ Assistant Professor in English and Research Supervisor, KIIT Deemed to be University; \\ Email: ipsita.teacher@gmail.com; ORCID ID: https://orcid.org/oooo-ooo2-4584-7470
}

\begin{abstract}
Ecospirituality signifies spiritual evolution in consequence of one's response to ecological stimuli. Mamang Dai is a powerful tribal voice from the North East India who has explored in depth the theme of Ecospirituality in her books. The article explicates those ecological attributes manifested in Dai's works which form an integral part of the spiritual voyage of her characters. In an attempt to define the term 'Ecospirituality,' a review of existing literature has been placed at the beginning which is followed by discourse analysis of the five works of fiction which Dai has to her credit. All the arguments put forth in the article are substantiated by textual evidence from her books. The analysis of the said texts is followed by a conclusion suggesting a way forward. The present study examines the elements of Ecospirituality in Dai's 'fictional' works alone hence the exclusion of her books of non-fiction. It shows how a slew of ecospiritual elements are identifiable in the fictional outputs of Dai and yet the theme demands more elaborate treatment due to the advent of new theoretical constructs.
\end{abstract}

Keywords: Ecospirituality, North East, Ecospiritualism, Mamang Dai, ethnography, folklore, Deep ecology, topography, ethnic identity

\section{Introduction}

The North East India has been able to transfer the grandeur and beauty of its landscape on to its literary canvas with a good number of writers and poets from this region attaining fame and critical acclaim over the last few decades. One of these literary artists is Mamang Dai who is a versatile author of four poetical works, two non-fiction books and five works of fiction apart from hundreds of newspaper columns that she has penned down. Being naturally gifted with an enticing topography, the North East region has produced literary texts into which Nature and its significance in human life have automatically negotiated their ways. The land and its people are inseparably assembled to constitute the spiritual ecosystem of the region. As rightly pointed out, "the land is all they have and need, for they are spiritually related to it" (Rexlin and Latha, 2018, p.602) . The Metaphor used in the title of this article is justified in the sense book after book, the writer has dealt with the North Eastern ethnography revealing in vivid details to her readers at

(C) AesthetixMS 2020. This Open Access article is published under a Creative Commons Attribution Non-Commercial 4.0 International License (http://creativecommons.org/licenses/by-nc/4.0/), which permits non-commercial re-use, distribution, and reproduction in any medium, provided the original work is properly cited. For citation use the DOI. For commercial re-use, please contact editor@rupkatha.com. 
large the concealed tribal world of her native soil with its pagan "faith" and unyielding "belief system" (Kapparath, 2017).

\section{Methodology}

A review of available literature has been done in order to establish clearly the framework of Ecospiritualism. Following this, the five primary texts have been critically examined by implementing the discourse analysis method. Each finding is validated by evidence taken from the primary texts as well as critical insights gained from the secondary ones. A conclusion has been placed at the end as a suggestion of the way forward.

\section{Literature Review}

Spirituality is the awareness of "inner truth", "peace", "beauty" and "purity" which is the intent of all traditional religions. It, therefore, soars "beyond the merely religious" and acts as a "ladder to human perfection" (Nandakumar, 2017, p.85). The spiritual odyssey is also in a way the existential journey or the consistent attempt to discover the essence of one's own self by trying to situate the self in the cosmos.

In his research article on eastern philosophy, Rory Mackay explains the concept of "Spirituality" as laid down in the Vedas. "Spirituality" is a cosmic energy. To understand "spiritualism," it is crucial to comprehend the cosmology which is the study of the origin of universe. What the Vedanta says about the great spirit can be summed up in the following way: A great spirit lives within the universe and the earth represents its presence. In the universe, which is a mythological wonder, the existence of life circle is known as "samsara." This circle cannot be completed without an ultimate reality which is "Brahma." Human intellect functions around two dots such as "Jiva" and "Jagata." 'Brahma' is the third dot which completes the circle and the creation is its manifestation. Brahma with its supreme power is called "Prakriti." which is therefore divine. Brahma without Prakriti is "Shunya" or a big zero, but when combined with "Prakriti" Brahma is "Paramatma" or "Ishvara." Hence all concepts of divinity come from "Prakriti" or Nature (Mackey, 2019).

Bron Taylor points out that the study of "Earth and nature-based spirituality" has expanded across continents of late, and there are diverse practices associated with Ecospirituality such as "mountaineering, new shamanic ritualizing, and states of consciousness" (Taylor, 2001, p. 175). The "ecological ethic" which Tarun Roy highlights in his article is "that all life forms are interdependent parts of the Supreme Being" (Roy, 2014, p.44). Critics like Rosemary Radford Reuther even argue that "There is no ready-made ecological spirituality and ethic in past traditions (Reuther, 1992, p.206). However, "despite significant diversity, a sense of connection and belonging to nature (sometimes personified as a transforming, if not transcendent power)" is what is held in common by all exponents of Ecospiritualism (Taylor, 2001, p. 193).

\section{Scope of the Article}

The present study is based on a critique of the Ecospiritual elements with specific reference to the five books of fiction of Mamang Dai. The word 'fiction' is defined in the following manner: "In an inclusive sense, fiction is any literary narrative, whether in prose or verse, which is invented instead of being an account of events that actually happened. In a narrower sense, however, 
fiction denotes only narratives that are written in prose (the novel and short story)" (Abrams \& Harpham, 2015, pp.130-131). The study, therefore, excludes Dai's writings in the other genres.

\section{Ecospirituality in the tribal folklores of The Sky Queen}

The advocates of Ecospiritualism "argue that pre-modern cultures have always treated nature with respect" (Nayar, 2020, p.251). A remarkable feature of Ecospiritualism highlighted in Mamang Dai's illustrated children's book The Sky Queen is the nature-orientation of tribal folklores dealing with the subject matter of the beginning, middle and end of civilizations. There are two folklores, to be specific, in this slender book: a folkloric account of "Biri Bote... the mighty monarch of SiliSidong, the Water Kingdom" (Dai, 2005, p.9) projected as the destroyer and that of "Nyanyi Myete," (Dai, 2005, p.19) the Sky Queen, projected as the preserver. The book does not establish the Trinity of creation, preservation and destruction in the strict sense although there has been a reference to the beginning of life: "At the dawn of life when there was nothing but endless blue, there sprang a civilization known as Kojum-Koja"(Dai, 2005, p.3) Both The Sky Queen and Once Upon A Moontime have atavistic roots in the North Eastern tribal folklores and "myths" (Nongbri, 2006, p.1) which reflect upon the animistic faith of the natives constituting their ecospiritual base.

\section{Creation of Universe and Divine Justice in Nature Highlighted in Once Upon a Moontime}

Dai's second illustrated story book, Once Upon a Moontime, is soaked deep in the North Eastern tribal "folkloric" (Deka, 2011, p.175) culture. As Pramod Nayar states, Ecospiritualism is "An important strand of ecofeminism" that "retrieves older myths and religious beliefs in which nature is revered" (Nayar, 2020, p.251). The creation myth is what the first story "How the World was Made" (Dai, 2005, p.1) deals with. The story recounts how "Before the earth was made, everything was water," (Dai, 2005, p.1) when there were "two brothers in the sky" (Dai, 2005, p.1) who "thought there should be human beings on earth." (Dai, 2005, p.3).

The story also recounts how there was the formation of earth:

...they [the two brothers] called the wind from the four quarters. The east wind blew yellow dust. The south wind red dust. The north wind black dust. And the west wind blew the dust round and round and mixed it up together until the earth was formed. (Dai, 2005, p.4)

From there on, the reader gets to read about how other natural bodies such as the mountains, "the Lohit river"(Dai, 2005, p.6), etc. came into being.

In the third folklore in the same series, Dai once again reverts to the creation myth. The story "The Sun and the Moon"(Dai, 2005, p.19) begins with the proclamation that "At the beginning of time there was no moon. There were just two suns who gave light and heat to the world"(Dai 2005, 19). The tale also underlines the principles of natural justice as when the younger sun decides to burn the earth and thus inflicts suffering in living beings by "pouring" down "all" the "heat" (Dai, 2005, p.20) it carries within him, it gets punished by the sky and the elder sun. It gets thrown into a "pool of mud"(Dai, 2005, p.26) and it not only grows pale but also has marks of mud on his face which are visible even now on the moon's surface. From that day onwards the younger sun-turned moon doesn't dare to come out "as long as the elder sun"(Dai, 2005, p.26) is there in the sky. 
Just like in the poem "The Tables Turned", Wordsworth writes, "One impulse from a vernal wood/ May teach you more of man,/ Of moral evil and of good,/ Than all the sages can," (Wordsworth, 1798) here it is, through this folklore, underlined by Dai that Nature acts not just like a pronouncer of moral judgment but also like a spiritual instructor telling human beings the difference between good and evil and lets them reflect on the repercussions of evil deeds. "The folktales reflect that there is a close association of Nature with the Adis" (Phukan, 2015, p.69), notes Sudipta Phukan in a scholarly article.

\section{The 'Pahari' Spiritual Practices in The Legends of Pensam}

In The Legends of Pensam there is an ethnographic substantiation of tribal spiritualism. In the 'Prologue,' Dai underlines the magnanimity of her clan, "I was born in the mountains, in a village where boys kicked rocks around pretending at football (Dai, 2006, p3). She reflects on the ecospiritual consciousness of the Adis:

Like the majority of tribes inhabiting the central belt of Arunachal, the Adis practice an animistic faith that is woven around forest ecology and co-existence with the natural world. (Dai, 2006, p1)

The book is replete with mountain rituals and shamanic rituals and it underlines the strong belief of tribal clans in the unfailing effects of these rituals. For instance, Biribik the water Serpent is the embodiment of all spirits and everyone in the Adi tribe believes whenever there is an unusual sight in the river something bad is certainly going to happen in the village. Then an ancient Serpent ritual is performed to heal and cure the sufferings. In fact, this is the theme reiterated throughout book.

Among the significant elements of Ecospirituality, the ones that find a place in this book are legends, myths and pahari pratha or mountain rituals and spiritual practices associated with the North Eastern tribes. In the 'Author's note' to Legends of Pensam, Dai establishes the North East topography as well as the North East ethnography:

Arunachal Pradesh in North East India, bordering Bhutan, China and Myanmar, is one of the largest states in the country, and also one of the greenest. It is the homeland of twenty-six tribes with over one hundred and ten sub-clans..... The mightiest of its rivers is the Siang... Siang valley... is the territory of the Adi tribe who are the subject of this book. (Dai, 2006, p.1)

It is the same valley which finds a mention in a seminal ethnographical work of Verrier Elwin who is regarded as one of the greatest champions of the North East.

Siang, the happiest of the NEFA Divisions, is the home of bright colours, lovely weaving, dancing, singing and an enchanting people formerly known collectively by the Assamese word 'Abor' which means independent, but who now call themselves Adi or hillmen. (Elwin, 2017. p. xv)

\section{Dissociation from Nature Leading to Spiritual Degeneration in Stupid Cupid:}

Dai's Stupid Cupid lays bare how the desires of the flesh and modern capitalism attempt to disrupt the human-Nature relationship. When Adna, a hill dweller turns to New Delhi for a more advanced and fulfilling life, she gets entangled in various strings attached to the material pursuit. 
She confesses, "though my home was in the hills, I was city bred, and things happened" (Dai, 2009, p.3).

The first catch for her is an extramarital affair with a married man which completely blindfolds her moral vision. She thinks as long as a relationship is based on true love it cannot be held as adultery. Soon she knows that her aunt has bequeathed her a bungalow. The second catch for her is her decision to turn that estate into a guest house where couples and pairs can spend time without being interrogated about their relationship status. This she precisely does so that she has no problem in having her "current beau" (Dai, 2009, p.3) with her at any point of time. The place quickly turns into a hub of clandestine affairs and illicit relationships. Thus, in Adna we see how alienation from Nature precipitates spiritual degeneration.

A question Adna keeps asking in her heart of hearts embarks her on a spiritual quest: "Everyone is looking to rediscover something. But... what?" (Dai, 2009, p.2). She keeps wondering what it is which is "bigger, better, brighter" and "purer" (Dai, 2009, p.2). What is perfectly alright for her physiological self begins to disturb her mentally. Her so called "love nest" suffocates her so much that she confesses,

Despite all the liberal talk, I couldn't bring myself to live permanently in the love nest and so with Amine's help I had found a rented apartment close to where she lived. (Dai, 2009, p.3)

The pivotal point of Adna's soul searching is the moment she knows the reason why and in which circumstances her aunt died leaving her property to Adna. She realizes that there are lot of similarities between her aunt's life and her own life and she now dreads the kind of ending her aunt's life had. When she feels that her homeland is calling her she responds to the call and a radical atheist now turns into a devotee of Nature by regaining the lost connections with her spiritual roots.

In the final pages, Dai beautifully portrays this spiritual awareness. It is as if spiritual essence is endowed to the hills:

The lights on the hill were coming on one by one and as if to compete with them, more fireflies began to gleam on their secret errands... Looking up I saw the prayer flags on the green hill. They were so tall they halted the wind. The wind stopped, listened and moved on. Perhaps there are more gods and goddesses standing all around us than we will ever know... Otherwise why would our souls rise up like birds and fly away with the sound of prayer bells tinkling across the Himalayas? (Dai 2014, 155)

Man-Nature interface illuminates the consciousness. The various physical bodies of nature, be it the sea or the river, the tree or the mountain, when it connects spiritually with a human being, self-awareness deepens. Arup Pal has shown in one of his articles how "spiritual well-being comes after the sublime understanding when the height's physical buoyancy interacts with the human soul" (Pal, 2000, 111)

\section{Being one with Nature in the Spirit in The Black Hill:}

Dai's hill motif, which appears in tales after tales, emerges as a microcosm of her fictional ecosystem. The hill has the natural vigour of an altitude that can transform anything corporal into ethereal, anything transient into everlasting and anything mundane into divine. The Black Hill, opens and closes with Gimur, the central character standing on the hill. The book recounts 
Gimur's journey or rather the journey of her soul. Kajinsha, a tribal youth, who has a mind of his own is the other major character of the novel. The third character is Father Nicolas Krick, a nontribal character who is a Christian missionary. He arrives on the hills to spread the Gospel and targets Tibet through Assam. Historically, the book marks the advent of Christian spiritualism on the pagan soil. It is a complex narrative which lets at one point to think that Kajinsha has probably killed the Priest whose preaching is seen as a threat to the Pagan faith or the tribal spiritualism, but in reality he has not committed the crime. In the end, Kajinsha is accused of the murder he did not commit and is killed in the prison leaving Gimur behind with her sense of loss.

Throughout the book, Gimur is often seen contemplating nature, experiencing oneness with the hill and the forest. In the final pages of the novel, we get to witness her Ecospiritual healing and a much needed spiritual stretching:

The sky above shone with a soft, clear light. She could inhale the grandeur of the sky...Her soul was returning to her. Beyond this spot the true forest would begin....She gazed up at the sky. In the gathering darkness a smile stretched her pale face. (Dai, 2014, p.288)

Her smile is the sign of her spiritual reunion with Kajinsha, her lover. An epic spiritual journey thus culminates in a spiritual expansion delineated in the closing lines of the novel: "The gods are bystanders. And I am earth and Kajinsha is the sky and we have looked at each other and will look at each other like this for a million years" (Dai, 2017, p.289). Here is a reference to the myth of the Sky and the Earth as creative principles. There are multiple myths of the Earth and the Sky recorded by Verrier Elwin at least two of which deserves a mention in this context. In the first one, Elwin notes,

At first, there was no earth and sky: there were only two great eggs. But they were not ordinary eggs...From one came the Earth, from the other the Sky, her husband. Now the Earth was too big for the Sky to hold in his arms... The Earth... made herself paliable and the mountains and valleys were formed... When the Sky made love to Earth, every kind of tree and grass and all living creatures came into being" (Elwin, 2017, pp.15-16).

Elwin sums up the second myth of sky saying,

The Earth and Sky are lovers...but the lovers must be separated, for so long as they cling together, there is nowhere for their children to live. In a Minyong tradition, after their separation, The Earth always longed to return to her husband to be one with him again. (Elwin, 2017, p.xxi)

\section{Conclusion}

The concept of ecospiritualism is a dynamic one hence undergoing change from time to time with newer perspectives added even with a slight change in the bio-socio-cultural milieu. There has been a significant shift in the anthropocentric emphasis on "ecology" to a bio-centric stress on "deep ecology" and from "deep ecology" to "radical environmentalism" demanding attention and involvement of creative writers to communicate through their works that

This earth is our home and our creator.... The mountains, the seas, the endless prairie, the grasslands, the wetlands, the deserts and rainforests are all infinitely precious, both manifesting and partially constituting a proper object of religious concern. From this perspective, current human practices toward nature are a sacrilege - a gross irreverence toward this hallowed place. (Hettinger, 1995, p.94) 
Although different forms of ecospiritualism are espoused in the writings of Mamang Dai, she is yet to explore some of the more recent shapes this concept has taken. If Dai continues with her preoccupation with the theme in her future works, she needs to explore varied forms of ecospiritualism experienced not just in her immediate ecospiritual space but in the broader and more universal ecosphere. If she goes for a wider assortment of this theme, it will be able to mitigate the subjectivity, singularity of vision and limited significance of her fiction and square with the larger canvas of the ecospiritual framework.

\section{References:}

\section{Primary sources:}

Dai, M, (2005) Once Upon a Moontime. New Delhi: RaveIndia, 1-28. . (2005) The Sky Queen. New Delhi: RaveIndia, 1-32. . (2006) The Legends of Pensam. Gurgaon: Random House, 1-192 . (2009) Stupid Cupid. Gurgaon: Random House, 1-155. . (2014) The Black Hill. New Delhi: Rupa Publications, 1-296.

\section{Secondary sources:}

Abrams, M. H. and Harpham, G. G. (2015) A Glossary of Literary Terms. Delhi: Cengage Learning,130-131.

Elwin, Verrier. (2017). Introduction. Myths of the North East Frontier of India. New Delhi:Gyan Publishing, $\mathrm{x}-439$.

Kapparath, M. (2017). “Arunachal Pradesh: Tribes and Traditions.” Outlook Traveller. Retrieved October 16, 2020, from https://www.outlookindia.com/traveller/ot-getaway-guides/arunachal-pradeshtribes-traditions.

Hettinger, Ned. (1995). “Ecospirituality: First Thoughts.” Dialogue \& Alliance 9, no.2 Fall-Winter. http://hettingern.people.cofc.edu/Hettinger_Ecospirituality.pdf. pp. 81-98.

Mackay, Rory. (2019). "What is Jiva? Understanding the Individual, the World and the Totality: The Essence of Vedanta Part II.” Retrieved October 16, 2020, from https://www.unbrokenself.com/jiva/.

Nandakumar, Prema. (2017). "The Elements of Mysticism in Milton's Paradise Lost and Sri Aurobindo's Savitri" The Critical Endeavour, 23, 85-89.

Nayar, Pramod K. (2020). Contemporary Literary and Cultural Theory. Noida: Pearson India, 251.

Nongbri, T. (2006). "Culture and Biodiversity: Myths, Legends and the Conservation of Nature in the Hills of North-East India". Indian Anthropologist, 36(1/2), 1-21. Retrieved October 16, 2020, from http://www.jstor.org/stable/419200oo

Pal, Arup. (2000). "The Ascent Within: Transformative Agency of the Nanda Devi in Bill Aitken's The Nanda Devi Affairs". Rupkatha Themed Issue on Indian Travel Narrative, 12(3) 110-118.

Phukan, Sudipta. (2015). "Lost Heritage of Folktales: A Glimpse at Mamang Dai's The Sky Queen and Once Upon a Moontime”. Indian Journal of Comparative Literature and Translation. 3 (2) 57-64.

Roy, Tarun. (2014). "Ecotheology in Gopinath Mohanty's High Tide, Ebb Tide”. Ravenshaw Journal of Literary and Cultural Studies, 4. 42-55. 
Reuther, Rosemary Radford. (1992). “Gaia and God: An Ecofeminist Theology of Earth Healing”. San Francisco: Harper San Francisco, 206.

Rexlin. T. and Latha, Mercy. (2018). "Mamang Dai's The Black Hill: A Story from Border Perpetuating Borderland Consciousness". International Journal of Recent Research Aspects, 600-603.

Taylor, Bron. (2001). "Earth and Nature-Based Spirituality (Part I): From Deep Ecology to Radical Environmentalism”. Religion. 31, 175-193.

Wordsworth, Williams (1798). The Tables Turned. Lyrical Ballads. Retrieved October 16, 2020, from https://www.poetryfoundation.org/poems/45557/the-tables-turned.

Mrs. Meghamala Satapathy is currently pursuing her Doctoral research in English in the area of Tribal fiction at KIIT Deemed to be University, Odisha, Bhubaneswar. Her areas of interest include Cultural Studies, Dalit Literature, Tribal Literature among others.

Dr. Ipsita Nayak is presently working as an Assistant Professor in English at KIIT Deemed to be University, Odisha, Bhubaneswar. Her areas of interest include World Literature, Postmodern Discourse, Postcolonial Literature, Cultural Studies and studies in Language and Communication. 